\title{
Reflections of the Distance Education Process on Higher Education: A Probability Course Example
}

\author{
Çiğdem İnci Kuzu (Corresponding author) \\ Department of Mathematics, Karabuk University \\ Demir Celik Campus 78050, Karabuk, Turkey
}

Tel: 90-370-418-9222Ｅ-mail: cigdemkuzu@karabuk.edu.tr

Received: May 5, 2021 Accepted: June 2, $2021 \quad$ Published: June 11, 2021

doi:10.5296/jei.v7i1.18603ＵRL: https://doi.org/10.5296/jei.v7i1.18603

\begin{abstract}
Evaluating the effects of the Coronavirus (Covid-19) pandemic on distance education applications in higher education is important for future practice. In this context, the aim of the study is to determine preservice mathematics teachers' conceptual-procedural knowledge level competencies and general thoughts about distance education in the distance education probability course in the department of mathematics teaching. In the study, a questionnaire consisting of 18 questions was prepared in the light of the literature as a data collection tool for 52 preservice mathematics teachers who took the probability course with distance education in the 2020-2021 academic year. After the implementations, one-to-one interviews were made with the lecturer conducting the course. The data of the study were analysed with the descriptive analysis method. As a result, it was determined that the conceptual-operative knowledge of the preservice mathematics teachers in the probability course in the distance education process was at a medium level. Although it was determined that the participation in online lessons was quite low compared to the lessons taught face-to-face, the preservice teachers mostly followed the lessons from asynchronous recordings, but there was no low performance or unwillingness in the preservice teachers who attended the lessons online. It has been determined that the biggest problem with distance education is the internet access and the low reliability of evaluation process. To increase the reliability, it has been determined that the transition to camera-controlled exams and the use of the safe exam browser (SEB) have been introduced.
\end{abstract}

Keywords: Covid-19, Distance education, Preservice mathematics teachers, Probability course 


\section{Introduction}

The Covid-19 pandemic, experienced in the spring semester of 2020, spread to 7 continents and 188 countries, including Turkey, and went down in history. Necessary precautions have been taken in the field of education as in every field in Turkey against the new type of Corona virus, which is emerging in China and spreading rapidly all over the world (İnci Kuzu, 2020). Due to the pandemic, the Higher Education Council decided to suspend higher education for three weeks on March 16, 2020 in Turkey. Afterwards, it was decided to move to distance education as compulsory. Since the pandemic unexpectedly got out of control, all education units were adapted to distance education and continued with online and asynchronous lessons. Although today's young people have grown up in the digital age and are defined as Generation Z, they are accustomed to the traditional education system and the planning is made in accordance with face-to-face education, the distance education method, which is obligatory except for normal conditions, has been generally regarded by students as strange (Can, 2020). This situation is similar for educators. However, with the continuation of higher education with distance education for nearly a year, a situation has emerged in 2021 in which all components of education harmonize. The first application of distance education, which is widely applied in the World due to the pandemic, started in 1962 with the decision of the University of South Africa to implement it based on the use of multimedia, radio and television broadcasting and printed materials. With the establishment of the British Open University in 1969, a process in which open universities were established began (Genç, 2019). Clark (2020) emphasized the history of distance education in his study and drew attention to the fact that this method has been applied by means of books, radio, and newspapers since the past. In this context, distance education is not a concept that has recently entered the educational process. Keegan (1980) defines distance education with six basic components. These are teachers, students, learning groups in a different environment, technological materials, providing two-way communication and educational institutions. The role of educational institutions here is to determine the quality of distance education.

When the literature on distance education is examined, it is emphasized that there are disadvantages as well as advantages of distance education. Traditional education is a different learning design than distance education. Traxler (2018) states that distance education is more advantageous when examined in terms of accessibility and economy. According to Arat and Bakan (2014), features such as providing access to larger groups, being independent of time and place, and being suitable for individual learning are among the advantages of distance education. The features that make distance education advantageous are that it provides equal opportunities in education, offers lifelong learning opportunities and provides a low-cost learning environment (Odabaş, 2003). In addition, the various course materials it provides are among the advantages of distance education (Kırık, 2016). The lack of effective communication between the course instructor and the students in distance education, where many problems are experienced in addition to its advantages, is seen as the biggest problem. Elcil and Şahiner (2014) stated in their study that student-teacher interaction was weak and there was a lack of motivation in the distance education process. Altiparmak, Kurt, and Kapidere (2011) listed the problems experienced in the distance education process as the 
access problem of students without financial means, the requirement to enter the system programmatically, the technical infrastructure problem and the possibility of technical problems from time to time.

Ustati and Hassan (2013) stated that students have difficulties in interacting with the distance education process. Similarly, Duran (2020) stated in his study that uneasiness caused by the limited interaction in distance education negatively affects individuals' perceptions of education.

Due to the pandemic in Turkey, education studies and exams at all educational levels have been postponed to future dates, and online exams have been put into use during the evaluation phase. Head of the UNESCO Department of Education Policy Chang (UNESCO, 2020) stated that 58 out of 84 countries where he was conducting research were postponed scheduled exams, 23 countries introduced alternative methods such as online or homework, 22 countries continued exams, and 11 countries cancelled the exams.

Inci Kuzu (2020) stated that there is an intense load on online exams in this process, but the adequacy of every information given in education cannot be evaluated online. She also stated that it would be necessary to offer accelerated learning opportunities to students when schools are opened to identify learning deficiencies. As stated by Can (2012), a measurement and evaluation unit should be established, infrastructure deficiencies should be eliminated, access problems should be eliminated in exams and reliability should be ensured to perform the measurement and evaluation in open and distance education.

In online courses and exams, instructors at all levels of education have a great responsibility. They should be able to manage every stage from the learning process to the evaluation process well. Teachers can provide such environments only if they have certain competencies. Apart from the applied courses in teacher education, the partial or complete sustainability of distance education applications with the transition to normal conditions is related to many parameters such as access to technological opportunities and knowledge levels of students and lecturers in distance education courses (Baturay \& Türel, 2012).

Individuals who will work in a profession that requires practice, such as teaching, should have acquired certain skills in addition to the knowledge required by teaching, even with distance education. One of the most difficult courses for teachers and students is the probability course (İnci Kuzu \& Uras, 2018). In this context, it is important to determine the conceptual-procedural knowledge level competencies of preservice mathematics teachers about the distance probability course and the opinions of the preservice teachers and the course coordinator. The subject of probability develops the ability to think based on possibility, which is independent creative thinking and a basic way of thinking. Probability, including concepts that can facilitate daily life and probability concepts are important for individuals (Özmantar, Bingölbali, \& Akkoç, 2008), learning probabilistic thinking methods in the acquisition of reasoning skills, which is one of the mathematical process skills (Borovenick \& Peard, 1996; MEB, 2018) and that probability supports proportional reasoning skills, requiring probability concepts to be at all educational levels, starting from pre-school period (NCTM, 2000). The main problem is that the concepts are intangible about 
probability, which is usually taught by classical and traditional methods. These concepts need to be embodied to positively affect students' interest and attitude towards the course (İnci Kuzu \& Uras, 2019).

With the significant changes and effects of the Covid-19 pandemic on education around the world, the need and approach of distance learning has come to the fore. The pandemic has shown that the understanding of the necessity of continuing learning without interruption, that more investments should be made in distance education and, that it is necessary to give importance to alternative learning approaches (especially distance education applications) instead of traditional education approaches. It should not be forgotten that distance education practices have important advantages not only for the sole purpose of supporting formal education in normal times, but also in some crisis situations (pandemic, wars, disasters, forced migration, etc.) and should be taken into consideration by policy developers. The purpose of this research is to evaluate the reflections of the Covid-19 pandemic on distance education applications in Turkey and to make suggestions for the future. In this context, the sub-problems of the research were determined as follows to determine the conceptual-operational knowledge level competencies of mathematics preservice teachers in the probability course given by distance education in the mathematics teaching program during the pandemic period, and the thoughts of the prospective teachers and the course instructor about this process.

(1) At the end of the distance education process, what is the level of preservice mathematics teachers' conceptual knowledge on probability?

(2) At the end of the distance education process, what is the operational knowledge of the mathematics preservice teachers regarding the subject of probability?

(3) What are the opinions of the preservice teachers about the distance education process?

(4) What are the lecturer's thoughts on distance education?

\section{Method}

\subsection{Research Model}

In the study, a descriptive scanning model, one of the qualitative study designs, was used to determine preservice teachers' conceptual and procedural knowledge levels about the probability course in the distance education process, as well as the opinions of preservice teachers and lecturers about this process. The scanning method, on the other hand, tries to define the situation, individual or object, which is the subject of the research, directly under their own conditions. It is important to be able to observe and determine the current situation properly (Karasar, 2002). The scanning model defines and explains what the situations are. Thus, the opportunity to understand the events, institutions and groups well is provided and the relationships between them are determined (Neuman, 2007). 


\subsection{Participant}

In qualitative studies, it is mostly studied with a small number of samples that are interconnected and examined in detail (Miles \& Huberman, 2016). Participants of the study were 52 preservice teachers studying in the $2^{\text {nd }}$ grade of the Mathematics Education Program of a state university in Turkey during the 2020-2021 academic year, and a lecturer (Prof. Dr.) who conducted the probability course face-to-face for 4 semesters and distance education for one semester. Purposeful sampling method was used while selecting the participants of the study. In purposeful sampling, researchers purposefully designate research locations to collect data about the main case (Creswell, 2017). 36 of the preservice teachers constituting the study group were male and 16 of them were female. The GPA of 36 of the participants was 2-2.99, and 14 of them were between 3-4. The reason for wanting to work with second grade prospective teachers was that these candidates took the probability course with distance education.

\subsection{Data Collection Tools}

To determine the reflections of distance education on higher education, a test with 18 questions on the probability course was prepared by the researcher by scanning the literature and taking the opinions of an academician who has conducted probability courses for 12 years regarding the questions in the test. The first 7 questions of the test prepared in accordance with the undergraduate program of the department of mathematics teaching probability course consist of conceptual knowledge about probability, 4 questions of operational knowledge questions on probability problems, and the last 7 questions of multiple-choice questions for determining the opinions of preservice teachers about distance education. The tests were administered to preservice teachers in the form of an online test with camera control. Answers were collected within 1 hour by e-mail. In addition, an average of one hour interview was held with the lecturer conducting the course. During the interview, open-ended questions about the distance education process were asked and a voice recording was made within the knowledge of the instructor.

\subsection{Collection and Analysis of Data}

Ethics committee approval was first obtained to conduct research. The application of conceptual and operational knowledge tests was carried out by the researcher with a camera-controlled exam application due to the Covid-19 pandemic. 52 preservice teachers participated in the implementation phase, but two candidates were not included in the study because they could not open a camera, and the study was completed with the data of 50 preservice teachers. The test was completed in 40 minutes and the preservice teachers were not asked to write a name in to avoid grade anxiety. The researcher prepared a rubric for the analysis of the questions measuring the conceptual and operational knowledge level. While a maximum of 14 points can be obtained from the conceptual knowledge test with 7 questions, a minimum of 0 points can be obtained. 0 points for blank and incorrect answers, 1 point for partially correct answers and 2 points for correct answers (Table 1). 
Table 1. Conceptual knowledge test rubric

\begin{tabular}{|l|l|}
\hline Category & Point \\
\hline Blank and wrong answer & 0 \\
\hline Partially correct answer & 1 \\
\hline Correct answer & 2 \\
\hline
\end{tabular}

Sampling and scoring were prepared by two experts. Correct/Full/Explicit answer examples were taken from Başar and Oktay (2014) and, partially correct answers were determined according to these examples.

Scoring for the questions in the conceptual knowledge test is exemplified below.

(1) "What is probability?" Sample scoring for the question:

Blank/Wrong answer (0 Points): It is uncertainty.

Partly correct answer (1 Point): The probability of an event occurring is called probability.

Correct/Exact/Explicit answer (2 Points): Probability is the mathematical value or likelihood percentage, value of something happening or not.

(2) "What is permutation?" Sample scoring for the question:

Blank/Wrong answer (0 Points): Selection process.

Partially correct answer (1 Point): This is the solution method we use in ranking questions.

Correct/Exact/Explicit answer (2 Points): In mathematics, permutation is an ordered sequence in which each symbol is used at least once.

(3) "What is a combination?" Sample scoring for the question:

Blank/Wrong answer (0 Points): Sequential selection process.

Partially correct answer (1 Point): Selection process.

Correct/Complete/Explicit answer (2 Points): A combination is a selection made from a group of objects, regardless of order.

(4) "What is a dependent event?" Sample scoring for the question:

Blank/Wrong answer (0 Points): Dependent event: One result does not affect another.

Partially correct answer (1 Point): Dependent event: Events affecting each other.

Correct/Complete/Explicit answer (2 Points): Dependent event: If an event occurs or not depends on the realization of another event, that is, if the outcome of an event affects the outcome of another event, such events are called dependent events. 
(5) "What is an independent event?" Sample scoring for the question:

Blank/Wrong answer (0 Points): One result affecting another.

Partly correct answer (1 Point): It depends on the realization of an event.

Correct/Complete/Explicit answer (2 Points): If the occurrence of any of the two events does not change the probability of the other event, these events are called independent events.

(6) "What is the multiplication base?" Sample scoring for the question:

Blank/Wrong answer (0 Points): Multiplication of at least two or more functions.

Partially correct answer (1 Point): The situation where two dependent events occur.

Correct/Exact/Explicit answer (2 Points): The probability of the intersection of two events is equal to the probability of one event multiplied by the conditional probability of the second event, and this rule is called the multiplication rule.

(7) "What is the addition rule?" Sample scoring for the question:

Blank/Wrong answer (0 Points): It is the addition of two numbers to each other.

Partly correct answer (1 Point): For example, you need money to buy something, and two friends will buy it together. They both put the current money in your hand and are the result of adding both.

Correct/Exact/Explicit answer (2 Points): The total probability of occurrence of events that do not occur simultaneously (non-intersecting/disjoint) is equal to the sum of the probabilities of each event.

The scoring scale for the questions in the operational knowledge test is presented in Table 2.

Table 2. Scoring scale for questions in the operational knowledge test

\begin{tabular}{|l|l|l|}
\hline & Correct result (score) & Wrong result (score) \\
\hline The correct solution & 3 & 2 \\
\hline Partly correct solution & 2 & 1 \\
\hline Wrong solution & 1 & 0 \\
\hline No solution & 1 & 0 \\
\hline
\end{tabular}

According to Table 2, in the procedural knowledge test scoring;

$>3$ points for correct results achieved with the correct solution,

$>2$ points for the results that are wrong due to a calculation error with the correct solution, 
$>2$ points for correct results achieved through partially correct solution,

$>1$ point for incorrect results due to a partially correct solution, due to a calculation error,

$>1$ point for the correct results obtained with the wrong solution and correct guess,

$>0$ points for the results that are wrong due to a calculation error with the wrong, solution,

> 1 point for the correct results obtained by guessing without making a solution,

$>$ Scoring was given as 1 point for the wrong results that were predicted without a solution.

While the highest score was 12 that can be obtained from the operational knowledge test with 4 problems, the lowest score was 0 . The total scores obtained by the preservice teachers from the tests are given in Table 3 .

Table 3. Total score performance levels in the applied tests

\begin{tabular}{|l|l|l|l|}
\hline \multicolumn{2}{|c|}{ Conceptual knowledge test } & \multicolumn{2}{c|}{ Operational knowledge test } \\
\hline Total score & Performance level & Total score & Performance level \\
\hline $0-5$ & Low & $0-4$ & Low \\
\hline $6-10$ & Middle & $5-9$ & Middle \\
\hline $11-14$ & High & $10-12$ & High \\
\hline
\end{tabular}

According to Table 3, after scoring the conceptual knowledge test, the performance of the preservice teachers with a total score of 0-5 was evaluated as low, the performance of the preservice teachers with a score between 6-10 was evaluated as moderate, and the performance level of the preservice teachers between 11-14 was evaluated as high. After scoring the operational test, the performance of the preservice teachers with a total score of 0-4 was evaluated as low, the performance of the preservice teachers with a score between 5-9 was evaluated as moderate, and the performance level of the pre-service teachers between 10-12 was evaluated as high.

The frequencies of the total scores of the preservice teachers obtained from the tests were determined and their percentages were calculated. The responses of the preservice teachers were scored by two experts using a rubric based on predetermined criteria, and the consistency between the scores was examined (Miles \& Huberman, 1994). The agreement percentage for the concept test was $76 \%$ and for the knowledge test it is $81 \%$.

Content analysis was used in the analysis process of the data obtained from the opinions of preservice teachers and lecturers in the study. In content analysis, the researcher first 
develops categories related to the research subject. The data categorized with content analysis were interpreted with descriptive analysis. In descriptive analysis, data are summarized and interpreted according to predetermined themes (Özdemir, 2010). The use of descriptive statistics is one of the best methods in summarizing the data and interpreting the results obtained the research. In addition, direct quotations from the interviews with the instructor were presented.

\section{Results}

\subsection{Findings Regarding Conceptual Information}

Probability course conceptual knowledge of prospective mathematics teachers was evaluated basically, and the results were presented in Table 4 . When Table 4 was examined, the average point of the prospective teachers regarding the concept of probability was determined as 1.16. Other concepts that exceed 1 as the average score are the dependent event concept with 1.58 and the independent event concept with 1.56 average. The mean score for the permutation concept was 0.6 and the combination average was 0.96 . The most striking point in the findings related to the conceptual knowledge was that the means of the multiplication rule $(\overline{\mathrm{X}}$ $=0.34)$ and the addition rule $(\overline{\mathrm{X}}=0.26)$ were very low.

Some of the preservice teachers' answers regarding the concepts are as follows:

Regarding the concept of probability:

(0 Points): "Possibility is reasoning with numbers." (S5)

(2 Points): "It is the probability of something happening or not happening, either way or not. The basis of the concept of probability is understood by using probability-based approaches in solving problems related to games of chance." (S23)

Table 4. Conceptual knowledge frequencies based on questions regarding probability course

\begin{tabular}{|l|l|l|l|l|l|l|l|}
\hline Topics & Probability (f) & Permutation & Combination & $\begin{array}{l}\text { Dependent } \\
\text { Event }\end{array}$ & $\begin{array}{l}\text { Independent } \\
\text { Event }\end{array}$ & $\begin{array}{l}\text { Multiplication } \\
\text { Rule }\end{array}$ & $\begin{array}{l}\text { Addition } \\
\text { Rule }\end{array}$ \\
\hline Blank/Wrong answer (0 Points) & 13 & 20 & 8 & 1 & 1 & 38 & 41 \\
\hline Partially correct answer (1 Point) & 16 & 21 & 16 & 19 & 20 & 7 & 5 \\
\hline $\begin{array}{l}\text { Correct/Complete/Explanatory } \\
\text { answer (2 Points) }\end{array}$ & 21 & 9 & 16 & 30 & 29 & 5 & 4 \\
\hline$\overline{\mathrm{X}}$ & 1.16 & 0.6 & 0.96 & 1.58 & 1.56 & 0.34 & 0.26 \\
\hline
\end{tabular}

Regarding the concept of permutation:

(1 Point): "It is the process that determines how many different sorting procedures will be done." (S9) 
(2 Points): "Choosing different from each other. Sequencing is important." (S51)

Regarding the concept of combination:

(0 Points): “Sloppy picking.” (S55)

(1 Point): “Combination is selection." (S23)

Regarding the concept of dependents:

(0 Points): Dependent event: "One outcome does not affect the other." (S8)

(1 Point): Dependent event: “Events that affect each other." (S43)

(2 Points): "Dependent event: The occurrence of any of the two events is related to the other event." (S36)

Regarding the concept of independent event:

(1 Point): "It depends on the realization of an event." (S25)

(2 Points): "If the occurrence of any of the two events does not change the probability of the other event, these events are called independent events. " (S33)

Regarding the concept of the multiplication pedestal:

(0 Points): "Multiplication rule." (S1)

(2 Points): "The multiplication rule is the probability of finding independently by multiplying the probabilities of both events." (S17)

Regarding the concept of the addition rule:

(0 Points): "I can't really describe it." (S3)

(1 Point): "In dependent events, it is the occurrence or non-occurrence of one or the other." (S36)

The conceptual knowledge of preservice mathematics teachers about the probability course has been evaluated basically and the results were presented in Table 5 .

Table 5. Statistical information about conceptual information of probability course

\begin{tabular}{|l|l|l|l|l|l|l|}
\hline & $\mathrm{N}$ & Min. & Max. & $\mathrm{CV}$ & $\overline{\mathrm{X}}$ & SD (standard deviation) \\
\hline Conceptual information & 50 & 5 & 14 & $45.73 \%$ & 7.04 & 3.22 \\
\hline
\end{tabular}

When Table 5 was examined, it was seen that preservice teachers' conceptual knowledge of the probability course was 7.04 , which is close to the lower limit of the middle level. In the conceptual knowledge test, the student with the lowest score got 5 points, and the highest 
score got 14 points. In addition, the coefficient of variation $(\mathrm{CV})$ for conceptual knowledge was determined as $45.73 \%$.

\subsection{Findings Regarding Operational Information}

A four-question Operational Knowledge Test was applied to determine the procedural knowledge levels of the prospective teachers who participated in the study. The question asked to the candidates to evaluate their level of operational knowledge about mathematical expectation in the test was presented below:

(1) How many out of 1000 families with 4 children can we expect to have 2 boys and 2 girls? (The probability of being a boy and a girl will be equal)

The distribution of the scores the preservice teachers got for the question was presented in Table 6.

Table 6. Frequency and percentages of operational knowledge on mathematical expectation

\begin{tabular}{|l|l|l|}
\hline Score & $\mathrm{f}$ & $\%$ \\
\hline 0 & 4 & 8 \\
\hline 1 & 1 & 2 \\
\hline 2 & 2 & 4 \\
\hline 3 & 43 & 86 \\
\hline $\bar{X}=2.68$ & & \\
\hline
\end{tabular}

When Table 6 was examined, it was determined that almost all the candidates solved the given problem correctly and the students who made it wrong or incomplete calculated their probabilities correctly but had problems in multiplying by 1000 .

The question asked to preservice teachers to determine their operational knowledge about the addition and multiplication rule in the test was given below:

(2) A bag contains 9 tickets numbered with all numbers except 0 . When three tickets are taken from the bag at the same time; Find the probability that it is numbered "odd, even, odd" or "even, odd, even".

The distribution of the scores the preservice teachers got for the question was presented in Table 7. When Table 7 was examined, it was seen that $70 \%$ of the candidates got full points from the given problem in the question regarding the rule of addition and multiplication. Preservice teachers who get 0 points were a small part of the study group, $10 \%$. 


\section{Macrothink}

Table 7. Frequency and percentages of operational information on the addition and multiplication rule

\begin{tabular}{|l|l|l|}
\hline Score & $\mathrm{f}$ & $\%$ \\
\hline 0 & 5 & 10 \\
\hline 1 & 6 & 12 \\
\hline 2 & 4 & 8 \\
\hline 3 & 35 & 70 \\
\hline $\bar{X}=2.83$ & & \\
\hline
\end{tabular}

The question addressed to the candidates to determine their operational knowledge about probability distribution in the test is given below:

(3) It is known that $5 \%$ of the products produced by a shoe factory are defective. When buying 2 shoes from this factory by chance, arrange a probability distribution chart for the number of defective items.

The distribution of the scores the preservice teachers got for the question is presented in Table 8.

Table 8. Operational information frequency and percentages on probability distribution

\begin{tabular}{|l|l|l|}
\hline Score & $\mathrm{f}$ & $\%$ \\
\hline 0 & 9 & 18 \\
\hline 1 & 2 & 4 \\
\hline 2 & 4 & 8 \\
\hline 3 & 35 & 70 \\
\hline $\bar{X}=2.3$ & & \\
\hline
\end{tabular}

When Table 8 was examined, it was determined that $70 \%$ of the candidates got full points from the given problem in the question regarding the probability distribution. Preservice teachers who get 0 points were a small part of the study group, which was $18 \%$.

The question asked to the candidates to evaluate their operational knowledge regarding the discrete-continuous probability distribution in the test is given below:

(4) A representative group of 3 people will be formed from 4 math and 7 chemistry students with a grade point average above 85 . Calculate the probability of having at most one 
economist in the group.

The distribution of the scores the preservice teachers got for the question was presented in Table 9. When Table 9 was examined, $36 \%$ of the candidates on the question regarding the discrete-continuous probability distribution received full points from the given problem. The rate of preservice teachers who got 0 points was determined as $24 \%$.

Table 9. Frequency and percentages of operational information on discrete-continuous probability distribution

\begin{tabular}{|l|l|l|}
\hline Score & $\mathrm{f}$ & $\%$ \\
\hline 0 & 12 & 24 \\
\hline 1 & 3 & 6 \\
\hline 2 & 17 & 34 \\
\hline 3 & 18 & 36 \\
\hline $\bar{X}=1.82$ & & \\
\hline
\end{tabular}

The operational knowledge of prospective mathematics teachers about probability was evaluated in general and the results were presented in Table 10.

Table 10. Operational information on probability subject

\begin{tabular}{|l|l|l|l|l|l|l|}
\hline & $\mathrm{N}$ & Min. & Max. & D.K. & $\overline{\mathrm{X}}$ & $\mathrm{SD}$ \\
\hline Operational Information & 50 & 4 & 12 & $13.59 \%$ & 8.68 & 1.18 \\
\hline
\end{tabular}

When Table 10 was examined, it was seen that the preservice teachers' operational knowledge about probability is 8.68 , which was close to the upper limit of the middle level. In the procedural knowledge test, the student with the lowest score got 4, the student with the highest score got 12 points. In addition, the coefficient of variation for conceptual knowledge was determined as $13.59 \%$.

The frequencies and percentages of the opinions of preservice mathematics teachers about distance education were presented in Table 11 . When Table 11 was examined, $40 \%$ of the preservice teachers stated that they were not satisfied with the distance education process, $50 \%$ of them were moderately satisfied and only 5 preservice teachers were satisfied with this process.

$72 \%$ of preservice teachers stated that internet access was partially sufficient for distance 


\section{Macrothink}

Journal of Educational Issues

ISSN 2377-2263

2021, Vol. 7, No. 1

education, $24 \%$ of them internet was sufficient and only 4 preservice teachers stated that it was not sufficient.

It has been determined that preservice teachers generally use mobile phones (64\%) and laptop computers $(54 \%)$ to enter the lessons taught in the distance education process due to the pandemic. Desktop computer (8\%) and tablet (4\%) usage level was very low. The internet access problem among the technical problems experienced by the preservice teachers while attending the distance education lessons was determined as $32 \%$. This was followed by the problems of sound (28\%) and not being able to $\log$ into the system (18\%). $10 \%$ of the preservice teachers stated that they did not have technical problems. However, $10 \%$ of them stated that they had problems due to power outages. 


\section{Macrothink}

Journal of Educational Issues

ISSN 2377-2263

2021, Vol. 7, No. 1

Table 11. Preservice teachers' opinion frequency and percentages about distance education

\begin{tabular}{|c|c|c|c|}
\hline Questions & & $f$ & $\%$ \\
\hline \multirow{3}{*}{$\begin{array}{l}\text { What is your satisfaction with } \\
\text { distance education? }\end{array}$} & Low & 20 & 40 \\
\hline & Middle & 25 & 50 \\
\hline & High & 5 & 10 \\
\hline \multirow{3}{*}{$\begin{array}{l}\text { Is your internet access level } \\
\text { sufficient? }\end{array}$} & Yes & 12 & 24 \\
\hline & No & 2 & 4 \\
\hline & Partly & 36 & 72 \\
\hline \multirow{5}{*}{$\begin{array}{l}\text { What vehicle do you use to connect } \\
\text { to distance education? }\end{array}$} & Mobile & 32 & 64 \\
\hline & Tablet & 2 & 4 \\
\hline & Laptop & 27 & 54 \\
\hline & Desktop computer & 4 & 8 \\
\hline & Other & 3 & 6 \\
\hline \multirow{5}{*}{$\begin{array}{l}\text { What are the technical problems you } \\
\text { experience during the distance } \\
\text { education process? }\end{array}$} & Internet/Connection problems & 16 & 32 \\
\hline & Inability to login & 9 & 18 \\
\hline & Sound problem & 14 & 28 \\
\hline & Power outage & 5 & 10 \\
\hline & None & 5 & 10 \\
\hline \multirow{3}{*}{$\begin{array}{l}\text { What is your participation in } \\
\text { distance education lessons? }\end{array}$} & Online & 27 & 54 \\
\hline & Asynchronous & 4 & 8 \\
\hline & Online-Asynchronous together & 19 & 38 \\
\hline \multirow{3}{*}{$\begin{array}{l}\text { Do you think the evaluation process } \\
\text { has been done reliably and fairly? }\end{array}$} & Yes & 11 & 22 \\
\hline & Partly & 27 & 54 \\
\hline & No & 12 & 24 \\
\hline \multirow{3}{*}{$\begin{array}{l}\text { Would you like to continue your } \\
\text { distance education? }\end{array}$} & Let it not continue, let it be face to face & 36 & 72 \\
\hline & Get together distance-face to face & 12 & 24 \\
\hline & Let it not continue, let it be face to face & 3 & 6 \\
\hline
\end{tabular}

It was determined that $54 \%$ of the preservice teachers followed the lessons online, a small proportion of $8 \%$ followed them from the registrations asynchronously, and $38 \%$ followed them online and sometimes asynchronously. 
$24 \%$ of the preservice teachers participating in the study stated that they did not think the exams were reliable, more than half of them think that they were partially reliable and $22 \%$ of them think the exams were reliable.

$72 \%$ of the preservice teachers stated that they wanted face-to-face training as before, and $24 \%$ of them stated that distance and face-to-face education could be carried out together. A very small portion $(6 \%)$ of the 50 preservice teachers who participated in the study stated that they want to continue the lessons with distance education even if their lifestyle returns to normal.

\subsection{Views of the Lecturer Giving the Course}

In the research about the reflection of distance education in higher education, the probability course was chosen as an example and the views of the lecturer (L) who conducted the probability course in the department of mathematics teaching face to face for 4 semesters and distance education for 1 semester were given below.

L stated the level of participation of preservice teachers in online classes as follows.

L: "Almost all of the students attended the face-to-face classes. Participation in online classes is generally half of the class size and sometimes less, but they follow the course registrations asynchronously, especially during the pre-exam periods. There are students who ask the subjects that are stuck in their minds by entering the next lesson."

R: Does the low attendance at the classes affect you?

L: "A small number of students who attend the lesson are open to learning, who are really interested in the lesson, who are actively participating in the lesson, solving, and asking questions. During a two-week midterm exam period, almost no students attended the class. In these lectures, I taught the subject in a direct manner, and it was really boring. It is very important to be able to ask the student a question and get feedback."

R: Have you used any material or resources in your lessons, other than face-to-face training?

L: "I did not use a different resource. I prepared a power point presentation using the reference book I normally use and shared it as content in online collections. Then I shared the files with the students. In this process, if we consider in the context of both students and academic staff, our level of benefiting from technology has increased considerably."

R: Were there any difficulties for you and your students in online lessons?

L: "Yes, especially when there was a problem with internet access, the lessons became very inefficient and was a waste of time. Apart from the internet problem, we did not have much trouble and we can conduct the course with a question-and-answer method. I shared my phone number; they send me the question solutions through the WhatsApp application within the time I give them. There were even question solutions that I added to their exams as additional points. Thus, both the participation in the lesson increased and if we thought that the reliability of the online exam was low, I have achieved justice in my own way." 
R: Do you think online exams are unreliable?

L: "Unfortunately, in the distance education process, I think we have the most difficulties in this regard. We have recently found the solution to do camera-controlled exams, and we have started to use the SEB. I think if we can reliably handle the access problem and the evaluation phase, distance education can be continued in the theoretical courses for many departments in the next period. For the remote probability course, I can clearly say that face-to-face training was not missed. There is an increase in the exam grades compared to other years, but since I am not sure about the reliability of the exam, I do not take it as a basis, I say this according to their performance in the lesson. I guess the results of your research with camera supervision are not in this direction?"

(R: Researcher, SEB: It is a browser that prevents opening any other tabs or pages other than the exam on the computer during the exam process. To participate in the midterm and final exams, SEB must be installed on the computer to be used in the exam.)

When the views of the lecturer were examined, it was that the participation of students in the online probability course was reduced by half compared to face-to-face lessons, but there was no decrease in performance. It was seen that he stated that connection problem was experienced the most in the distance education process and that the evaluation phase should be more reliable.

\section{Discussion}

In this study, which aims to determine the effects of the distance education process, which started with the Covid-19 pandemic, on higher education, the probability course given in the department of mathematics teaching was examined as an example. According to the findings of the research, it was determined that preservice mathematics teachers' conceptual-operational knowledge about probability in the distance education probability course was generally at a medium level. Similar studies can be found in the literature, Ata (2014) stated in his study that similarly, preservice mathematics teachers in teaching probability with face-to-face education have a medium level of conceptual-operational knowledge on probability. Preservice teachers' operational knowledge levels were distributed more frequently than their conceptual knowledge levels. It was found that this is similar in Ata's (2014) study. As a result, when the lesson in distance education is well designed and with student participation, it can be successfully conducted without a significant decrease in success. As stated by İnci Kuzu (2020), students continued their lessons without losing their motivation despite all the negativities experienced in this process.

According to the opinions of the preservice teachers and the lecturer, it was determined that the problems encountered in the process of accessing distance education should be overcome with internet access and infrastructure problems. Similarly, Can (2020), in his study on the reflections of the pandemic process in Turkey, emphasized that the planning, coordination of open and distance education services, the adequacy of the infrastructure of the system, effective management and even supervision are of great importance and especially the establishment of the infrastructure. Given the increasing population of the world, distance 
education, which is an advantageous and reasonable method to provide fast and qualified education, will be effective when properly planned and infrastructure problems are solved.

It was stated by the preservice teachers and the lecturer that the reliability of the evaluation phase of the teaching process was a problem, although a camera-controlled exam was held recently to increase the reliability of the exams. In their study, Eroğlu and Kalaycı (2020) determined that the preservice teacher said that the reliability of the exams was low, and that the evaluation phase of the students should be extended to the whole process, regarding the problems they encountered during the evaluation phase in the distance education process. Since the results of the interim evaluation can be monitored throughout the teaching process to improve the process evaluation, activities, and behaviours of the course takers, it will be possible to reach the correct and timely result regarding the development of the students.

It has been determined that the preservice teachers attend the distance education lessons mostly with laptop computers and mobile phones, and most common technical problems were internet connection and sound problems. Karakuş et al. (2020) reached similar results in their work with Turkish teachers in this process. In addition, with distance education, it has also shown the importance that lecturers and students now must improve themselves in computer use. As Öztürk (2005) stated, access to information and communication technologies should be widespread and individuals should be developed in this regard.

According to the findings of the study, it was determined that participation in distance education lessons was low. The lecturer stated that he tried to include the student in the lesson by adding additional points to the exam grade for correct question solutions in the lesson to ensure the participation of the students in the lesson. It has been stated that when students' interest in mathematics is low, their participation in the lesson decreases (Gürbüz, 2007; Kuzu 2021). For this reason, it is important to ensure that students actively participate in the lessons in distance education.

Eygü and Karaman (2013) pointed out that to prevent social isolation in online lessons, it is beneficial to enable students to interact with components such as chat, feeling belonging to the lesson group, private messaging or face-to-face interaction, otherwise participation in the lesson would not be achieved.

Although most of the preservice teachers stated that they wanted the education to continue face-to-face after the pandemic, some of them stated that distance and face-to-face education could be continued together. To be beneficial in terms of the effectiveness and awareness of distance education from now on, it is necessary to attend at least one course online in each semester in higher education. The pandemic emerging in Turkey along with all countries of the world indicates that face-to-face education will evolve into a mixed model in which distance education is intertwined, in other words, mixed education practices.

The education and training method had to be changed in an unfamiliar way due to health reasons. While the necessary importance was not given to the distance education centres before the pandemic, the distance education centres, which attracted attention with the changes in the conditions, became the focus of the universities. The importance of distance 
education, which is applied for various purposes throughout the country, especially in universities, has gradually increased at all educational levels. Every element of distance education, the resources and designs used by educators, and the measurement and evaluation process have become important in this context.

Hoping that the pandemic process that took place in the spring of 2019-20 was a temporary process, both the theoretical and practical parts of education were continued online using various programs in education faculties as in other higher education institutions. With the development of solutions that will end the pandemic in the future and the normalization of living standards, theoretical courses in the mathematics education departments of the education faculty in Turkey will be able to continue with distance education if desired. Thus, the theoretically taught courses will be able to be followed by the students asynchronously with the course material and resource sharing. The problem in maintaining teacher education with distance education is that teaching practice lessons cannot be done properly without mingling with students without the school environment. In the study of Duran (2020) with university students, it was determined that the anxiety caused by the limited interaction in distance education in the students negatively affects the education perceptions of the individuals. However, it was stated that it is necessary to adapt to social change by overcoming negative perceptions in the field of education and making education continuous and effective (Gürbüz \& İnci Kuzu, 2018).

Against the pandemic, it can be said that all units of Higher Education Institutions in Turkey implement distance education opportunities in a fast and planned manner so that education can continue uninterruptedly. In distance education, alternative assessment-evaluation approaches should be developed by considering the dissatisfaction and deficiencies in the process of measuring and evaluating student success. In the distance education practices of countries for extraordinary situations, students' passing the course, measuring the success of the course and the evaluation phase should be planned and implemented correctly. Studies on the reliability, validity, security, transparency, and audibility of online exams should be increased.

For the measures and decisions to be taken against the pandemic, the establishment of a scientific board in the field of education like the one in the field of health will enable healthier and more appropriate decisions in the field of education and planning for a longer period. An "Education Scientific Committee" composed of experts from various levels and fields of education will be able to make scientific decisions more accurately by establishing a regular connection with other units on how the education process will continue in case of any extraordinary event.

As a result, it was determined that there was no significant change in the operational and conceptual achievement level of preservice teachers in the probability course given with distance education when compared to previous studies. On the other hand, it was determined that the most of preservice teachers want to return to face-to-face education. During the course process, it was determined that the biggest problem was in the evaluation phase. In this context, it is thought that this research will contribute to the development of the 
education plan-program in the future, in case the education continues completely, or some courses are carried out with distance education. This study has limitations in terms of time and because it is a single course review. In the ongoing pandemic process, the reflections of the distance education process on higher education, conducting more detailed research by enriching it with various data, and presenting it to the opinion of the educational scientists and ministries that direct the education process in line with the results obtained will be beneficial in planning the future process.

\section{References}

Altıparmak, M., Kurt, İ. D., \& Kapıdere, M. (2011). E-öğrenme ve uzaktan ĕgitimde açık kaynak kodlu ögrrenme yönetim sistemleri (pp. 319-327). Paper presented at the XI. Akademik Bilişim'11, Malatya. Retrieved from https://www.slideshare.net/egitimcininteknolojisi/altipar mak-kurt-ab112

Arat, T., \& Bakan, Ö. (2014). Uzaktan eğitim ve uygulamaları. Selçuk Üniversitesi Sosyal Bilimler Meslek Yüksekokulu Dergisi, 14(1-2), 363-374. Retrieved from https://dergipark. org.tr/tr/pub/selcuksbmyd/issue/11302/135148

Ata, A. (2014). Öğretmen adaylarının olasılık konusuna ilişkin kavramsal ve işkemsel bilgi düzeylerinin incelenmesi (Unpublished master's thesis, Eskisehir Osmangazi University, Eskişehir, Turkey).

Başar, A., \& Oktay, E. (2014). Uygulamalı Istatistik. Erzurum: Erzurum Kültür ve Eğitim Vakfi Yayınevi.

Baturay, M. H., \& Türel, Y. K. (2012). Çevrimiçi uzaktan eğitimcilerin eğitimi: E-öğrenmenin yükselişi ile beliren ihtiyaç. In G. Eby, G. T. Yamamoto \& U. Demiray (Eds.), Türkiye'de e-öğrenme: Gelişmeler ve Uygulamalar III (pp. 1-21). Eskişehir: Anadolu University.

Borovenik, M., \& Peard, R. (1996). Probability. In A. J. Bishop (Ed.), International Handbook of Mathematics Education (pp. 239-287). Netherlands: Kluwer Academic Publishers. https://doi.org/10.1007/978-94-009-1465-0_9

Can, E. (2012). Açık ve uzaktan eğitimde akreditasyon yeterlilik düzeyinin incelenmesi (Unpublished doctoral dissertation, Marmara University, İstanbul, Turkey).

Can, E. (2020). Coronavirüs (Covid-19) pandemisi ve pedagojik yansımaları: Türkiye'de açık ve uzaktan eğitim uygulamaları. Açıköğretim Uygulamaları ve Araştırmaları Dergisi, 6(2), 11-53. Retrieved from https://dergipark.org.tr/tr/pub/auad/issue/55662/761354

Clark, J. T. (2020). Distance education. In E. Iadanza (Ed.), Clinical Engineering Handbook (pp. 410-415). Florence-Italy: Academic Press. https://doi.org/10.1016/B978-0-12-813467-2. 00063-8

Creswell, J. W. (2017). Eğitim araştırmaları: Nicel ve nitel araştırmanın planlanmast, yürütülmesi ve değerlendirilmesi. İstanbul: Edam. 
Duran, L. (2020). Distance learners' experiences of silence online: A phenomenological inquiry. International Review of Research in Open and Distributed Learning, 21(1), 81-98. https://doi.org/10.19173/irrodl.v20i5.4538

Elcil, Ş., \& Şahiner, D. (2014). Uzaktan Eğitimde İletişimsel Engeller. Sosyal ve Beşeri Bilimler Dergisi, 6(1), 21-33. Retrieved from https://dergipark.org.tr/tr/pub/sobiadsbd/issue/ 35980/403685

Eroğlu, F., \& Kalayc1, N. (2020). Üniversitelerdeki zorunlu ortak derslerden yabancı dil dersinin uzaktan eğitim uygulamasının değerlendirilmesi. Türk Ĕ̆itim Bilimleri Dergisi, 18(1), 236-265. https://doi.org/10.37217/tebd.683250

Eygü, H., \& Karaman, S. (2013). Uzaktan eğitim öğrencilerinin memnuniyet algıları üzerine bir araştırma. Sosyal Bilimler Dergisi, 3(1), 36-59. Retrieved from https://dergipark.org.tr/ tr/pub/kusbd/issue/19375/205547

Genç, H. (2019). Uzaktan eğitimde kurumsal modeller ve öğrenen destek hizmetleri uygulamaları. Açıöğretim Uygulamaları ve Araştırmaları Dergisi, 5(2), 29-48. Retrieved from https://dergipark.org.tr/en/pub/auad/issue/45710/576565

Gürbüz, N., \& İnci Kuzu Ç. (2018). Sosyal Bilgiler Öğretmen Adaylarinin Sosyal Bilgiler Dersi Öğretim Programinda Yaşadiklari Matematik Kaynakli Sorunlar. Uluslararası Ĕ̆itim Bilim ve Teknoloji Dergisi, 4(3), 141-154. Retrieved from https://dergipark.org.tr/tr/pub/ uebt/issue/41983/498319

Gürbüz, R. (2007). Olasılık konusunda geliştirilen materyallere dayalı öğretime ilişkin öğretmen ve öğrenci görüşleri. Kastamonu Eğitim Dergisi, 15(1), 259-270. Retrieved from https://dergipark.org.tr/tr/pub/kefdergi/issue/49108/626721

İnci Kuzu, Ç. (2020). Covid-19 Pandemisi Sürecinde Uygulanan İlkokul Uzaktan Eğitim Programi (EBA TV) İle İlgili Veli Görüşleri. Milli Eğitim Dergisi, 49(1), 505-527. https://doi.org/10.37669/milliegitim.720556

İnci Kuzu, Ç., \& Uras, M. (2019). İlköğretim matematik öğretmenliği bölümü öğretim elemanlarının matematik öğretiminde materyal kullanımı ile ilgili görüşleri. Current Research in Education, 5(1), 23-33. Retrieved from https://dergipark.org.tr/tr/pub/crd/issue/ 45590/470904

İnci Kuzu, Ç., \& Uras, M. C. (2018). The subjects that the pre-service classroom teachers perceive as difficult in elementary mathematics curriculum. Universal Journal of Educational Research, 6(10), 2153-2159. https://doi.org/10.13189/ujer.2018.061013

Karakuş, N., Ucuzsatar, N., Karacaoğlu, M. Ö., Esendemir, N., \& Bayraktar, D. (2020). Türkçe öğretmeni adaylarının uzaktan eğitime yönelik görüşleri. RumeliDE Dil ve Edebiyat Araştırmaları Dergisi, 19, 220-241. https://doi.org/10.29000/rumelide.752297

Karasar, N. (2002). Bilimsel Araştırma Yöntemi. Ankara: Nobel Yayın Dağıtım.

Keegan, D. J. (1980). On defining distance education. Distance Education, 1(1), 13-36. 
https://doi.org/10.1080/0158791800010102

Kırık, A. (2016). Uzaktan eğitimin tarihsel gelişimi ve Türkiye'deki durumu. Marmara Iletişim Dergisi, 21, 73-94. Retrieved from https://dergipark.org.tr/tr/pub/maruid/issue/22159/ 238064

Kuzu, Ç. İ. (2021). Aile ve Öğretmen Yaklaşımlarının Matematik Kaygı Düzeyine Etkisi ile İlgili Öğrenci Görüşleri, Ekev Akademi Dergisi, 25(85), 113-128. https://doi.org/ 10.17753/Ekev1844

MEB. (2018). Matematik Dersi İlköğretim Programı (İlkokul ve Otaokul 1, 2, 3, 4, 5, 6 , 7 ve 8. siniflar). Retrieved from http://mufredat.meb.gov.tr/Dosyalar/201813017165445-MATE MAT\%C4\%B0K\%20\%C3\%96\%C4\%9ERET\%C4\%B0M\%20PROGRAMI\%202018v.pdf

Miles, M. B., \& Huberman, A. M. (1994). Qualitative data analysis: An expanded sourcebook (2nd ed.). Sage Publications, Inc.

Miles, M. B., \& Huberman, A. M. (2016). Nitel veri analizi. Ankara: Pegem Akademi.

NCTM (National Council of Teachers of Mathematics). (2000). Principles and standarts for school mathematics. Reston, VA: NCTM.

Neuman, L. W. (2007). Basic of social research: Qualitative and quantitative approaches. USA: Pearson Education.

Odabaş, H. (2003). İnternet tabanlı uzaktan eğitim ve bilgi ve belge yönetimi. Türk Kütüphaneciliği, 17(1), 22-36. Retrieved from http://www.tk.org.tr/index.php/TK/article/ view/167/162

Özdemir, M. (2010). Nitel veri analizi: sosyal bilimlerde yöntembilim sorunsalı üzerine bir çalışma. Eskişehir Osmangazi Üniversitesi Sosyal Bilimler Dergisi, 11(1), 323-343. Retrieved from https://dergipark.org.tr/tr/pub/ogusbd/issue/10997/131612

Özmantar, M. F., Bingölbali, E., \& Akkoç, H. (2008). Matematiksel kavram yanılgıları ve çözüm önerileri. Ankara: Pegem Akademi.

Öztürk, L. (2005). Türkiye'de dijital eşitsizlik: Tübitak-bilten anketleri üzerine bir değerlendirme. Erciyes Üniversitesi İktisadi ve İdari Bilimler Fakültesi Dergisi, 24, 111-131. Retrieved from http://iibf.erciyes.edu.tr/dergi/sayi24/lozturk.pdf

Traxler, J. (2018). Distance learning-Predictions and possibilities. Education Sciences, 8(35), 1-13. https://doi.org/10.3390/educsci8010035

UNESCO. (2020). Exams and assessments in COVID-19 crisis: Fairness at the centre. Retrieved from https://en.unesco.org/news/exams-and-assessments-covid-19-crisis-fairness-centre

Ustati, R., \& Hassan, S. S. S. (2013). Distance learning students' need: evaluating interactions from Moore's theory of transactional distance. Turkish Online Journal of Distance Education, 14(2), 292-304. Retrieved from https://www.learntechlib.org/p/131628 


\section{Copyright Disclaimer}

Copyright for this article is retained by the author(s), with first publication rights granted to the journal.

This is an open-access article distributed under the terms and conditions of the Creative Commons Attribution license (http://creativecommons.org/licenses/by/3.0/). 